\title{
THE EFFECTIVENESS OF STRUCTURED INQUIRY BASED MODULE TO IMPROVE MENTAL MODEL OF CONCEPT MOLE
}

\author{
Hidayati $^{1}$, Minda Azhar*2, Rahadian Zainul ${ }^{3}$ \\ ${ }^{1}$ Chemistry Education, Magister Programme of Chemistry Education, \\ Faculty of Mathematics and Natural Sciences, FMIPA, Universitas Negeri Padang, Indonesia \\ ${ }^{2}$ Chemistry Education, Divison of Biochemistry, Chemistry Department, \\ Faculty of Mathematics and Natural Sciences, FMIPA, Universitas Negeri Padang, Indonesia \\ ${ }^{3}$ Chemistry Education, Division of Physical Chemistry, Chemistry Department, \\ Faculty of Mathematics and Natural Sciences, FMIPA, Universitas Negeri Padang, Indonesia
}

Email : minda_azhar@yahoo.com

\begin{abstract}
Mole concept is the essential part of chemistry learning and has been the prerequisite to learn other chemistry concepts. Learning source used has not yet connected the three levels of representations completely. The inability to connect the three levels of representations might affect students' learning outcome and mental model. This study aims to find out the effect of structured inquiry based module on students' mental model of mole concept. The design of study is Randomized Control Group Postest Only Design. There were 141 students from two Senior High Schools in Padang recruited as the samples of study. The instruments are two-tier mental diagnostic test and semi structured interview. The result of $t$-test on hypotheses reveals that the mental model of mole concept in experimental group was higher than that of control group of both schools. Hence, it can be said that there is effect of module on students' mental model of mole concepts in both schools.
\end{abstract}

Key words: mental model; module; mole concept; structured inquiry.

\section{INTRODUCTION}

Chemistry is the branch of science that involves several abstract concepts that students might misinterpret and learn (Gayeta et al., 2017). The objective of science education is to enable students to enhance their understanding on abstract concepts (Edmundson, 2000). One of chemistry materials that most of students might find difficult to learn as it deals with abstract concept is mole concept.

Textbook is learning resource that a teacher frequently uses in teaching and learning process. It is learning component which has the highest level of interaction for students. In other words, students develop their paradigm and get the information from textbook. A teacher prepares, carries out and evaluates the teaching and learning activity by referring to the content of textbook (Sitepu, 2005: 114).

Misinterpretation might derive from the content of textbook as well as teacher (Stojanovska et al,. 2014). Hence, a textbook used in teaching and learning process which aims to direct students to understand the concept possibly misleads the students. In some cases, it can also cause the students misinterpret the concept. As stated by Eilks et al (2012) and Tasker (1998), misunderstanding stems from the illustration of textbook and the animation used.

Textbook used at schools has not yet presented chemistry materials comprehensively which is teaching chemistry through interconnection among three levels of representations. The representations consists of macroscopic (concrete), submicroscopic (illustrated by models related to the structure of atom, molecule and ion) and symbolic (symbols, formulas, stoichiometry reaction, graphs, etc) which is fruitful in understanding and in chemistry instructions (Johnstone, 1991).

In teaching and learning process, a teacher uses concrete and visual teaching aid as diagram of representation, oral and verbal description, symbolic representation and physical model to convey the meaning of new concepts and terms. The three levels of representations demonstrate that students are required to know macroscopic, submicroscopic and symbolic in order to learn and understand chemistry (Gabel et al, 1998).

The understanding of chemistry depends of the representation since it assists the development of mental model. Three levels of chemistry representations are connected and reflected on students' mental model (Chittleborough et al., 2002). The development of mental model is commonly used to predict, test new concepts 
and solve the problems in science instructions (Halim et al, 2013). A teacher should know how students develop their own mental model in order to ensure they do not do it mistakenly because mental model is the essential part in constructing a theory and chemistry practices (Nahum et al, 2004; Coll, 2008). Mental model shows concepts and ideas on individuals' mind which they use to describe and explain phenomena (Jansoon et a.l, 2009).

Students must be involved actively in using the teaching material. It is suggested to have teaching material which allows the students to formulate problems, collect and organize the data to prove hypotheses and make the conclusion. Those steps are done in sequence so the students are able to find the concept of learning material by themselves in accordance with learning objectives. In collecting and organizing data, teaching material should present and connect three levels of chemistry representations. As the students know and connect the three levels of chemistry representations well, the mental model will develop. The order of those steps is the phase in structured inquiry learning.

\section{METHOD}

The design of study is randomized control group postest only design. The design is as follows,

Table 1. Research Design

\begin{tabular}{lll}
\hline Group & Treatment & Post test \\
\hline Experimental & $\mathrm{X}$ & $\mathrm{T}$ \\
Control & $\mathrm{Y}$ & $\mathrm{T}$ \\
\hline
\end{tabular}

Note:

$\mathrm{X}$ : the instruction with module

Y: the instruction without module

T: Post test

This study was conducted at two Senior High School Padang namely SMA N 3 Padang and SMA N 12 Padang. The sampling technique used in the present study is cluster purposive sampling. The experimental group is Science Class 2 and the control group is Science Class 3 in SMA N 3 Padang. Meanwhile, in SMA N 12 Padang, the experimental group is Science Class 1 and the control group is Science Class 5. The experimental groups were taught by using structured inquiry based module while the control groups were taught using the textbook used at school.

The instruments used in the study are two-tier diagnostic test and structured interview. The students' answers are grouped in four categories namely the answer correct on both levels, correct on the first level but wrong on the second level, wrong on the first level but correct on the second level, and wrong on both. Two-tier test developed by Treagust applies the scoring system that the answer is correct if both statements are correct. However, the scoring system can be developed as follows:

Table 2. Scoring system of Two-Tier Diagnostic Test

\begin{tabular}{lll}
\hline Answer & Score & Level of Understanding \\
\hline Correct answer, correct reason & 2 & A lot \\
Correct answer, wrong reason & 1 & A little \\
Wrong answer, correct reason & 1 & A little \\
Correct answer, correct reason & 0 & None \\
\hline
\end{tabular}

Moreover, the data were analyzed in relation to the understanding on macroscopic, submicroscopic, and symbolic levels and the possibility of misunderstanding. The data were then grouped in five categories and analyzed using the formula below:

percentage $=\frac{\mathrm{n}}{\mathrm{N}} \times 100 \%$

$\mathrm{n} \quad$ : the number of students on the indicator of mental model

$\mathrm{N} \quad$ : the total number of students

100 : fixed number (Zafri, 1999: 83) 
Table 3.The Category of Mean Scores Two-Tier Diagnostic Test

\begin{tabular}{llll}
\hline Number. & Score & Category & Mental Model \\
\hline 1. & $<25$ & Very poor & Unclear model \\
2. & $25-49$ & Poor & Intermediet 1 \\
3. & $50-74$ & Moderate & Intermediet 2 \\
4. & $75-99$ & Good & Intermediet 3 \\
5. & 100 & Excellent & Target \\
\hline
\end{tabular}

The data were analyzed descriptively and quantitatively. The effectiveness of structured inquiry based module can be seen through the hypotheses of students' learning outcome in experimental and control group. Prior to hypotheses testing, normality and homogeneity tests were carried out.

\section{FINDING AND DISCUSSION}

The result of study reveals that there is effect of structured inquiry module on students' mental model of mole concept. It is shown on the table below:

Table 4. The Result of hypotheses testing of students' mental model

\begin{tabular}{lllllll}
\hline School & Group & N & Mean & S & Sig. & \\
\hline SMA N 3 & Experimental & 35 & 84,89 & 9,427 & 0,011 & $\mathrm{H}_{0}$ is rejected \\
Padang & Control & 36 & 79,11 & 9,282 & 0,011 & \\
SMA N 12 & Experimental & 35 & 81,06 & 9,362 & 0,000 & $\mathrm{H}_{0}$ is rejected \\
Padang & Control & 35 & 68,91 & 12,030 & 0,000 & \\
\hline
\end{tabular}

Hypotheses

$\mathrm{H}_{0} \quad$ : there is no effect of module on students' mental model

$\mathrm{H}_{1} \quad$ : there is effect of module on students' mental model

Table 4 shows that the significance value of SMA N 3 Padang is 0.011 on the significance level $(\alpha=$ 0.05). The significance value is smaller than 0.005 suggesting that $\mathrm{H}_{0}$ is rejected. Similarly, at SMA N 12, the significance value is 0.000 suggesting that $\mathrm{H}_{0}$ is rejected. It indicates that there is effect of module on students' mental model.

The questions were developed by involving three levels of representations. The levels are connected in order to avoid misunderstanding. Out of four questions, there are three questions involving mathematical calculations which require the students to connect three levels (macroscopic, submicroscopic and symbolic). The result of two tier diagnostic test is as follows:

Table 5. Students' mental model of mole concept

\begin{tabular}{|c|c|c|c|}
\hline \multirow{2}{*}{ School } & \multirow{2}{*}{ Mental Model } & \multicolumn{2}{|c|}{ Students' mental model } \\
\hline & & Experimental & Control \\
\hline \multirow{5}{*}{ SMAN 3 Padang } & Target & $34,29 \%$ & $28,57 \%$ \\
\hline & Intermediate 3 & $60,00 \%$ & $45,71 \%$ \\
\hline & Intermediate 2 & $5,71 \%$ & $25,71 \%$ \\
\hline & Intermediate 1 & - & - \\
\hline & Unclear & - & - \\
\hline \multirow{2}{*}{ SMAN 12 Padang } & Target & $22,86 \%$ & $14,29 \%$ \\
\hline & Intermediate 3 & $71,43 \%$ & $62,86 \%$ \\
\hline
\end{tabular}




\section{Article of Thesis, HIDAYATI, 161760004/2016, MAGISTER PENDIDIKAN KIMIA FMIPA

$\begin{array}{lll}\text { Intermediate } 2 & 5,71 \% & 22,86 \% \\ \text { Intermediate } 1 & - & - \\ \text { Unclear } & - & -\end{array}$

Form the table above, students' answer analysis on two tier diagnostic test demonstrates that students of SMA N 3 Padang in experimental group (34.29\%) and control group (28.75\%) are in the category of target mental model. Meanwhile, students of SMA N 12 Padang in experimental (22.86) and control group (14.29\%) are in the category of target mental model. The mental model suggests that students' concept in the form of picture and explanation is precise scientifically.

At SMA N 3 Padang, most of students in experimental group (60\%) and control group (45.71\%) are in the category of intermediate 3. It means that students' mental model in form of picture and explanation is acceptable scientifically. Students of SMA N 12 Padang at experimental (71.43\%) group and control group $(62.86 \%)$ are the in the category of intermediate 3 . There are more students at both control groups at SMA N 3 and SMA N 12 in the category of intermediate 2 than that of experimental groups. This mental model shows that students' concept in the form of structured figure is close to the truth of science. The category of students' mental model indicates the level students' understanding of mole concept.

The category of students' model mental describes how students understand each test item of mole concept. The analysis of students' mental model of mole concept based on the question number is illustrated in Table 6.

Table 6. Students understanding of mole concept

\begin{tabular}{|c|c|c|c|c|c|c|c|}
\hline \multirow{2}{*}{ School } & \multirow{2}{*}{ Question } & \multicolumn{3}{|c|}{ Experimental } & \multicolumn{3}{|c|}{ Control } \\
\hline & & A lot & Little & None & A lot & Little & None \\
\hline \multirow{4}{*}{$\begin{array}{l}\text { SMA N } 3 \\
\text { Padang }\end{array}$} & 1 & 77,14 & 22,85 & - & 61,1 & 38,9 & - \\
\hline & 2 & 82,86 & 11,43 & 5,71 & 75 & 22,22 & 2,78 \\
\hline & 3 & 57,14 & 40 & 2,86 & 50 & 50 & - \\
\hline & 4 & 97,14 & 2,86 & - & 88,9 & 11,1 & - \\
\hline \multicolumn{2}{|c|}{ Total Percentage } & 78,57 & 19,29 & 4,29 & 68,75 & 30,56 & 2,78 \\
\hline \multirow{4}{*}{$\begin{array}{l}\text { SMA N } 12 \\
\text { Padang }\end{array}$} & 1 & 65,71 & 34,28 & - & 48,57 & 42,86 & 8,57 \\
\hline & 2 & 77,14 & 22,86 & - & 62,86 & 37,14 & - \\
\hline & 3 & 65,71 & 31,43 & 2,86 & 28,57 & 20 & 14,29 \\
\hline & 4 & 88,57 & 8,57 & 2,86 & 100 & - & - \\
\hline \multicolumn{2}{|c|}{ Persentase Skor Total } & 74,28 & 24,29 & 2,86 & 60,00 & 33,33 & 11,43 \\
\hline
\end{tabular}

The researchers of previous studies used two-tier diagnostic test to find out the level of students' understanding of particular topic. The series of two-tier diagnostic test is administered in order to find out students' understanding which later the questions and test items are confirfed through interview to figure out the types of student's mental model (Lin, 2007:778).

Table 5 demonstrates that the students from both schools, experimental and control groups, had the highest understanding level as they answered question number 4, molar mass. It suggests that most of students knew how to solve the calculation of mass 1 mole of substance which involves conversion from atomic mass in atomic mass unit (macroscopic) to mass 1 mole of substance in gram unit and to decide the total mole of substance (atom, molecule or ion) (submicroscopic). Students could connect the three levels (macroscopicsubmicroscopic-symbolic) once they answered correctly and determine the correct reason.

Little understanding category was found when the students of both schools answered question number 3 , deciding mass of 1 atom in gram unit. In this question, students could not connect submicroscopic and symbolic level well. Due to calculation of completion process, students firstly knew the number of particles (atom, molecule, or ion) of 1 mole of substance. It is proven that in experimental and control groups SMA N 3 Padang 
students' mental model of mole concept is in the category of intermediate $2(5.71 \%$ and $25.71 \%)$. Meanwhile, students' model mental in experimental and control groups SMA N 12 Padang is in the category of intermediate $2(5.71 \%$ and $22.86 \%)$. Mental model of mole concept in the category of intermediate 2 would affect students' understanding on the problem solving concerning with the number of particles which due to students' inability in connecting the three levels of representation especially transformation from submicroscopic level to symbolic level.

Students' inability to connect the three levels is due to the misunderstanding at submicroscopic level. It occurs when students answered question number 1 discussing the number of particles in 1 mole of substance. Students of experimental groups (22.85\%) and control groups (39.9\%) at SMA N 3 Padang are in the category of little understanding. On the other side, students of SMA N 12 Padang in the experimental groups (34.28\%) and control groups $(42.86 \%)$ are in the category of little understanding. It indicates that there are students who still got confused with the definition of 1 mole of substance either in two-tier diagnostic test (level one), or level two and even the students did mistakes in two levels.

Having analyzed the students' answers, students' misunderstanding is in the category of submicroscopic level in which the students did not understand that 1 mole of substance expresses the number of substance containing the number of the similar particles to the number of particles in 12 grams $\mathrm{C}-12$. The comparison between mole and particle in sample is defined as a means to enumerate atomic particle/molecule of substance through the amount of mass macroscopically (Staver and Lumpe, 1995).

The definition of mole indicates that mole has concept and quantitative calculation. The study in science education shows that the understanding of mole quantitatively (Gabel et al., 1984; Schmidt, 1990) while the understanding of mole conceptually, student should be able to perceive macroscopic world which they see in the real context as the number and connect it to the world of particle (Claesgens and Stacy, 2003).

Based on the data of Table 4 concerning with students' mental model of mole concept and Table 5, it demonstrates that the students in experimental groups of both schools outperformed the students in control groups. The difference might be caused by the use of structured inquiry model in experimental group.

The textbook used in control groups discussing mole concept still presents the formulae in solving mole concept. Mole is written as the comparison between mass (gram) and Relative Atom mass $\left(\mathrm{A}_{\mathrm{r}}\right)$ or Relative Molecule mass $\left(\mathrm{M}_{\mathrm{r}}\right)$. In addition, mole is defined as the equation of multiplication between molar volume and volume number of 22.4 liters. It is inappropriate in chemistry instruction because it can cause misunderstanding. This is in line with the study conducted by Pekdag et al., (2013) that $n=m / \mathrm{M}_{\mathrm{A}}$ is presented as the equation used to calculate "the total mole". This approach in textbook clearly neglects the basic quantity of the number of substance. The study conducted by Furio et al., (2000) shows that the chemistry teachers were perplexed with the description of "the number of substance" in which some considered it as mass, and/or the number of basic entities.

The learning of mole concept by using structured inquiry based module affected students' understanding and model mental. The module presents the steps of structured inquiry activities supplemented with interconnection of three levels of representations as well as conversion factors used in the process of finding out the concept. As a result, students could develop mental model of mole concept and enhance the understanding. By taking into account the teaching and learning process and learning source, the problems that might occur during teaching and learning activities can be minimized. The study conducted by Azhar (2004) revealed that the students in experimental group understood the lesson better through the use of labels compared to those in control group taught by using formulae.

The learning which can direct and involve students in using three levels of representation and connect those three can affect students' mental model development. Every individual uses mental model to solve problems by reasoning, explaining, predicting phenomena, or generating model expressed in varied forms (diagrams, graphs, stimulation or modeling, algebra/mathematics, even the description of words or printed writing, etc), and communicate with others (Borges and Gilbert, 1999; \& Greca and Moreira, 2001).

Having undertaken two-tier mental diagnostic test to find out students' understanding and mental model of mole concept, the write interviewed the students to clarify the answers and reasons chosen. The writer selected one experimental group student in each category (target, intermediate 3 and intermediate 2) and one control group student in the same categories. The result of interview shows that one of factors affecting students' mental model is the process of teaching and learning. There are numerous of mental model sources such as the instruction, language and words, daily experience, social environment and intuition. The textbook used by the teacher in teaching and learning process is one of teaching subcategories (Lin, 2007). The result of study by Lin (2007) exhibits that students' mental model in learning the topic of acids and bases belongs to mental model phenomena category. Students' mental model developed into scientific mental model.

The module can be used in chemistry instruction both in high accredited schools and moderate ones. Graph 1 showing the statistical analysis of the interactions between school criteria teaching and learning 
activities conducted by using module and students' mental model of mole concept indicate two straight lines that do not intersect each other. It shows that there is interaction between school criteria and teaching and learning using the module and students' mental model. Regardless of the school criteria (high and moderate), the teaching and learning using structured inquiry based module affects students' mental model of mole concept. Therefore, the teaching and learning using structured inquiry based module can be undertaken in all school criteria. Structured inquiry model is also effective and influences significantly students' mental model.

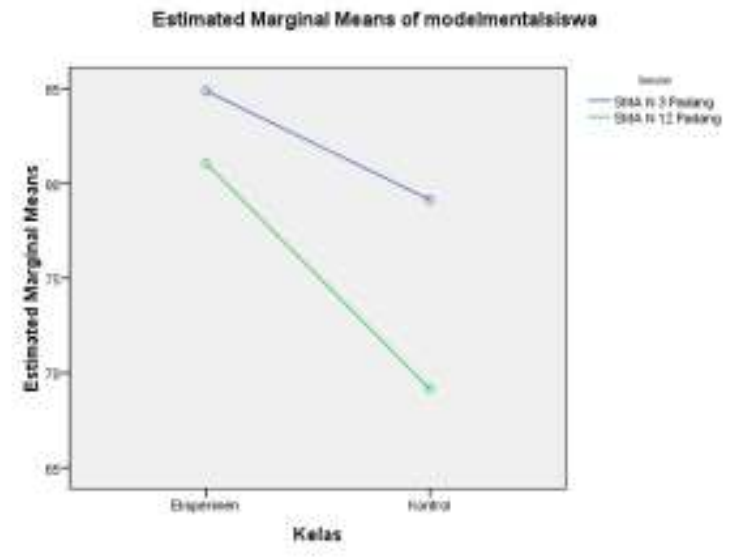

Graph 1.Graph of Interaction Between School Criteria And Learning Using Module on Students' Mental Model of Concept Mole

Structured inquiry model is appropriate to be applied in module of mole concept. This is accomplished by considering that the material of mole concept is mostly abstract and the teacher's guide is needed to take into account students' thinking ability based on the regular stages.

\section{CONCLUSION}

Based on the finding of study, the writer recommends the further studies to conduct in order to find out students' misunderstanding by using two-tier diagnostic instrument which were used in teaching mole concept and stoichoimetry reaction. Besides, the further studies can use other instruments to identify students' mental model of mole concept and stoichoimetry reaction in order to compare the results.

\section{REFERENCES}

Azhar, Minda. 2004. Pembelajaran. Konsep Mol dengan Cara Faktor-Label dan Cara Rumus. Jurnal Pembelajaran. Vol. 27, No. 2, Hal. 18. Tidak Diterbitkan.

Borges, A.T., \& Gilbert, J.K. 1999. Mental Models of Electricity. International Journal of Science Education, 21, Hal. $95-117$.

Chittleborough, G., Treagust, D. F., Mocerino, M. 2002. Constraints to the Development of First Year University Chemistry Students' Mental Models of Chemical Phenomena. Presented at the 11th Annual Teaching and Learning Forum for Western Australian Universities, Edith Cowan University, Australia.

Clasgens, J. \& Stacy A., 20003. What are Students' Initial Ideas About Amount of Substance? " Is There a Spesific Weight for a Mole?". Paper Presebted at the Annual Meeting of the American Educational Research Association (Chicago, IL, April, 2003).

Coll, R. K. 2008. Chemistry Learners' Preferred Mental Models for Chemical Bonding. Journal of Turkish Science Education (TUSED), 5(1), 22 - 47.

Edmundson, K. M. 2000. Assessing Science Understanding Through Concepts Maps. San Diego: Academic Press

Eilks, I., Witteck, T., \& Pietzner, V. 2012. The Role and Potential Dangers of Visualisation When Learning About Sub-microscopic Explanations in Chemistry Education, Centre Educ. Policy Stud. J., Vol. 2 hal: 125-145. 
Furio, C., Azcona R., Guisasola J., \& Ratcliffe M., 2000. Difficulties in Teaching the Concepts of 'Amount of Subtance' and 'Mole'. International Journal Science education, 22(12), 1285 - 1304.

Gabel, D.L. 1984. Problem Solving Skill of High School Chemistry Students. Journal Reesearch Science Teaching, 21(2), 221- 233.

Gabel, D.L , Samuel, K.V. \& Hunn. 1998. Understanding the Particulate Nature of Matter. Journal of Chemical Education, 64(8): 695-697.

Gayeta, E., Norrie \& Caballes, G., Dennis. 2017. Measuring Conceptual Change on Stoichiometry Using Mental Models and Ill-Structured Problems In a Flipped Classroom Environment. Asia Pasific Journal of Multidisciplinary Research, Vol. 5 No. 2, 104-113.

Halim N. D. A., Ali Moh. B., Yahaya N., Said Mohd. N. H. M S. 2013. Mental Model in Learning Chemical Bonding: A preliminary study, Procedia - Social and Behavioral Sciences 97, Hal. 224 - 228

Jansoon N., Coll R. K., \& Somsook E. 2009. Understanding Mental Models of Dilution in Thai Students. International Journal of Enviromental \& Science Education, Vol 4, No. 2 Hal. 147 - 168.

Johnstone, A.H. 1991. Why is Science Difficult to Learn? Things are Seldom What They Seen. Journal of Computer Assisted Learning: 75-83

Lin, W.J., \& Chiu, H.M., 2007. Exploring the Characteristics and Diverse Sources of Students' Mental Models of Acids and Bases.

Nahum T. L., Hofstein A. Mamlok-Naaman R., \& Bar-Dov Z. 2004. Can Final Examinations Amplify Students Misconceptions in Chemistry?. Chemistry Educatio: Research and Practice; 5(3).

Park, E.J., Light, G., Swarat, S., \& Denise, D. 2009. Understanding Learning Progression in Student Conceptualization of Atomic Structure by Variation Theory for Learning. Paper presented at the Learning Progressions in Science (LeaPS) Conference, June 2009. Iowa City, IA.

Pekdag, B., \& Azizoglu, N. 2012. Semantic Mistake and Didactic Difficulties in Teaching the "Amount of Substance" Concept: A Useful Model. Chemistry Education Research and Practice.

Schmidt, H.J. 1990 Secondary School Students' Strategies in Stoichiometry. International Journal Science Education. 12(4), $457-471$.

Sitepu, B. P. 2005. Memilih Buku Pelajaran. Jurnal Pendidikan Penabur No. 04/Th.IV/Juli, hlm. 113-120

Stojanovska M., Petruševski V. M., \& Šoptrajanov B. 2014. Study of The Use of The Three Levels of Thinking And Representation. CONTRIBUTIONS, Section of Natural, Mathematical and Biotechnical Sciences, MASA, Vol. 35, No. 1 Hal. 37-46

Straver, J. R., \& Lumpe, A. T. 1995. Two Investigations of Stidents' Understanding of The Mole Concept and Its Use in Problem Solving. Journal Research Science Teaching, 32(2), 177 - 193

Tasker, R., 1998. The VisChem project: Molecular level animations in chemistry — Potential and caution,UniServe Sci. News, vol. 9 hal. 12-16.

Zafri, 1999. Metode Penelitian Pendidikan. Padang: UNP.

Zainul, R., \& Jannah, A. R. (2017, February 6). Pengembangan Media Pembelajaran Asam Basa Menggunakan Aplikasi Android Berbasis Chemistry Triangle Kelas XI SMA/MA. https://doi.org/10.31227/osf.io/muh8y

Zainul, R., Handayani, D. P., \& Azra, F. (2018, February 1). Pengembangan Multimedia Prezi Berbasis Problem Based Learning ( $\mathrm{Pbl}$ ) Pada Materi Hukum-Hukum Dasar Kimia Kelas X IPA di SMAN 1 Bukittinggi. https://doi.org/10.31227/osf.io/yqpcm 